\title{
APPLYING DLTA STRATEGY ON TEACHING LISTENING COMPREHENSION
}

\author{
Darmawan Budiyanto ${ }^{1}$, Aprillitzavivayarti ${ }^{2}$, M. Rasyid Ridho ${ }^{3}$ \\ Dosen Universitas Tridinanti Palembang ${ }^{1}$, Dosen Universitas Jambi² \\ Mahasiswa Universitas Jambi ${ }^{3}$ \\ Jalan Inspektur Marzuki No. 2446, 20 Ilir Palembang
}

\section{Sur-el: Darmawanbudiyanto@univ-tridinanti.ac.id', lizayundi86@gmail.com², mrasyidridho95@gmail.com ${ }^{3}$}

Article info

Article history:

Received: 26-05-21

Revised : 05-06-21

Accepted: 12-06-21

Keywords:

Applying DLTA

strategy on teaching

listening

comprehension

Kata Kunci:

Menerapkan strategi

DLTA dalam

pemahaman

pengajaran

mendengarkan

\begin{abstract}
A B S T R A C T
The objective of this study is to find out whether it is effective or not to teach listening comprehension by using DLTA strategy. Population of this study was the seventh grade students of SMPN 46 Palembang in academic year 2020/2021 with the sample were taken from class VII. 1 consists of 34 students by using cluster random sampling. Method of this study was the pre - experimental with pre-test and posttest. The data were obtained by using test in 20 multiple choices. SPSS 17 was used to analyze data and the paired $t$ - test was applied. Based on analysis data, the writer found that the mean score in pre-test was 58.38 and in post-test were 72.06 . The result of value of t-obtained was 22.476, this score was higher than 2.0345 as its critical value. It means that the null hypothesis $\left(H_{a}\right)$ was rejected and alternative hypothesis $\left(H_{0}\right)$ was accepted.
\end{abstract}

Tujuan penelitian ini adalah untuk mengetahui apakah efektif atau tidak untuk mengajarkan pemahaman mendengarkan dengan menggunakan strategi DLTA. Populasi penelitian ini merupakan siswa kelas tujuh SMPN 46 Palembang tahun akademik 2020/2021 dengan sampel diambil dari kelas VII. 1 terdiri dari 34 siswa dengan menggunakan cluster random sampling. Metode penelitian ini adalah pre- eksperimental dengan pre-test dan post-test. Data diperoleh dengan menggunakan pengujian 20 soal pilihan ganda. SPSS 17 digunakan untuk menganalisis data dan diterapkan t-tes berpasangan. Berdasarkan data analisis, penulis menemukan bahwa skor rata-rata dalam pre-test adalah 58.38 dan dalam post-test adalah 72.06. Hasil dari nilai yang diperoleh T adalah 22.476, skor ini lebih tinggi dari 2.0345 sebagai nilai kritisnya. Ini berarti bahwa hipotesis null $\left(H_{a}\right)$ ditolak dan hipotesis alternatif $\left(H_{0}\right)$ diterima.

Direktorat Riset dan Pengabdian Masyarakat Universitas Bina Darma. 


\section{JURNAL ILMIAH \\ BINA EDUKASI \\ ISSN 1979-8598 E-ISSN: 2655-8378 \\ http://journal.binadarma.ac.id/index.php/jurnalbinaedukasi \\ Vol. 14, No. 1, Juni 2021, 59 - 68}

\section{INTRODUCTION}

In this modern world nowadays, language is a tool of communication used by most of people to communicate one to another. As we know, there are many kinds of languages that can be used in the world, when they want to speak each other. One of the languages which we are used in all parts of the world is English. In this case, English is internationally used as a means of communication for people all around the world. Today, it is very important to master English very well, because in this global era, people can communicate and interaction each other by using English in many sectors such as education, politic and economic.

In Indonesia, English is still as a foreign language which means that English is not used as a tool of communication among Indonesian people in daily activities. As a foreign language, learners of English sometimes find difficulties to acquire English from their social environment. Therefore, English teachers have to be creative not only in teaching English but also in giving the material in order to give more practice for students.

Based on the curriculum, the study of English involves the mastery of four skills, namely listening, speaking, reading and writing. One of the four language skills mentioned above, only the listening skill that will be concerned in this study because in general the knowledge is obtained through listening. Everyone heard the news through mass media or information directly face to face; it involves listening activities. Therefore, the teaching of listening has very important role in the learning process at school because a good listening skill is a beginning to produce good communication.

Listening is a key to all effective communication. Without the ability to listen effectively, messages are easily misunderstood. (Schafer, 2018) said that "listening comprehension in a foreign language is highly important in order to develop a natural feeling for using that language" (p.32). It means that listening is an activity process of constructing meaning from a stream of sounds to get meaning that is exchanged between listener and speaker. From the explanation above, it is clear that listening is important part that needs to be developed and it is essential skill in learning English. Therefore, the students must have ability in listening comprehension.

The lacks of student's ability in listening are caused by two factors; the first is the students' interest and the second lacks of the teaching method are used by the teacher who cannot motivate the students to learn. There are many ways to solve these problems; one of them is by using Directed Listening Thinking Activity (DLTA).

Directed Listening Thinking Activity (DLTA) is a strategy through reading a story aloud from teacher to the students and students make predictions through answering of some 


\section{JURNAL ILMIAH \\ BINA EDUKASI \\ ISSN 1979-8598 E-ISSN: 2655-8378 \\ http://journal.binadarma.ac.id/index.php/jurnalbinaedukasi \\ Vol. 14, No. 1, Juni 2021, 59 - 68}

questions from information that they heard in the story or picture that is given by teacher in front of the class. Barone et al., (2005, p. 243) said that "DLTA is a strategy that can be used to teach comprehension by reading aloud from the teacher to the students". It is explained that students listen what the topic is read by the teacher.

Based on the observation during having teaching practice of SMPN 46 Palembang, the students still have problems in listening comprehension. Although listening is one of the skills that should be learned and mastered, but in fact there are a lot of students of Junior High School have difficulties in listening comprehension especially to the seventh grade students. Therefore, the seventh grade students of SMPN 46 Palembang will be the object of the research because mastery of students in listening comprehension is still lack.

In previous studies, there are two studies which are related to this study. The first study conducted by Al-Khayyat (2015) entitled "The Impact of Directed Listening and Thinking Activity (DLTA) on developing University Students' listening competencies". The problem of this study is the application of Directed Listening and Thinking Activity (DLTA) to develop listening competencies to students of university. The objective of this study is to help students to improve their listening comprehension by using Directed Listening and Thinking Activity (DLTA) strategy.

The results of this study were the application of DLTA strategy could improve students' listening competencies. This study used quantitative method, namely quasi-experiment method. The population of this study was only first grade students of university. Which were consisting of 25 students (Group A) and 26 students (Group B). The samples were two groups; the control group from the group A and the experimental group from group B. The similarity of these two studies is about teaching strategy (DLTA) and the difference is the previous study used quasiexperiment method while the writer use pre-experiment method.

The second study conducted by Oktaviani, (2013) entitled "Implementation of Directed Listening and Thinking Activity (DLTA) strategy to increase listening skill to the fifth grade students of Elementary School”. The problem of this study is the application of Directed Listening and Thinking Activity (DLTA) strategy to increase listening skill to the fifth grade students of Elementary School in Surabaya. The objective of this study was to find out whether or not Directed Listening and Thinking Activity (DLTA) strategy increased students' skill in listening.

The result of this study was the application of DLTA strategy could increase students' listening skill. This study used quantitative method, namely pre-experimental method. The population of this study was at the fifth grade students of Elementary School in Surabaya. There are similarities and differences between this study and the previous study. The similarity of these two studies is about teaching strategy (DLTA) and the difference is the previous study used quantitative and qualitative method while the writer uses quantitative method. 


\section{JURNAL ILMIAH \\ BINA EDUKASI \\ ISSN 1979-8598 E-ISSN: 2655-8378 \\ http://journal.binadarma.ac.id/index.php/jurnalbinaedukasi \\ Vol. 14, No. 1, Juni 2021, 59 - 68}

It was hoped that the result of this study would give contribution some benefits for school, teacher, students, and writer in order to give the development in teaching and learning activities. For the School, it was expected that the finding of study would give a good contributions and effect positive to develop for the school in learning English, for the Teacher, this study was expected to be beneficial and could be used as a reference for the teacher in teaching listening more effectively in the effort to improve students' achievement in mastering English listening, for the Students, it could help students to comprehend the listening and to motivate the students to study hard in learning English especially in listening, and for the Writer, it was expected by conducting this study, it was increased the knowledge and the experiences on how to teach listening comprehension to the students through Directed Listening Thinking Activity (DLTA) strategy.

\section{RESEARCH METHOLOGY}

\subsection{The Concept of Listening Comprehension}

Listening is a basic of language learning. It is explained that listening is the first skill of four language skills. It should be gained by people before the other language skills. Downs (2008, p. 2) Stated that "Listening is a process of receiving what the speaker actually says (receptive orientation), constructing and representing meaning (constructive orientation), negotiating meaning by the speaker and responding (collaborative orientation) and creating meaning through involvement, imagination and empathy (transformative orientation)". It means that listening is to get the information that receiving what they heard. It also means listening not only to receiving, and transformative orientation but also to responding what the speaker say.

In addition to Nunan, (2003) said that "listening is an active, purposeful process of making sense of what we hear" (p.24). It means that listening is very active not only what the people heard but also connect it to other information they already known. Downs (2008) stated that "listening is defined as making an effort to hear something; to pay attention or heed" (p. 1). It is explained that listening is a something to hear and to understand when the speaker talk to the listener.

In conclusion, the activities of teaching listening in the classroom will hope students can get more interactive in listening and increase their understanding in listening comprehension. Teaching listening is not only - seem from what the speaker say to the listener but also from some activities that do by the teacher and the students. In this way, in teaching learning process of listening, students need high concentration to get the point what the teacher say. To get the information what they heard, the teacher make some point of story. The students just listen, response, and expected what they heard about the text. 


\section{JURNAL ILMIAH \\ BINA EDUKASI \\ ISSN 1979-8598 E-ISSN: 2655-8378 \\ http://journal.binadarma.ac.id/index.php/jurnalbinaedukasi \\ Vol. 14, No. 1, Juni 2021, 59 - 68}

\subsection{The Concept of Directed Listening Thinking Activity (DLTA)}

DLTA is a strategy that can be used to teach comprehension by reading aloud from the teacher to students". It is explained that students listen what the topic is read by teacher, (Barone et al., 2005, p. 221). Meanwhile, Dalton (2007, p. 326), DLTA follows a three-part framework preparing for listening with discussion and questions was reading the text with few interruptions, and the discussing the text. In other word, this strategy can make the interaction of teacher and students in the classroom. This is a development from DLTA strategy where students directly get the information from material that given by teacher through listening activity. The students can increase their comprehension in interactive of listening.

\subsection{The Procedures of Directed Listening Thinking Activity (DLTA)}

According to Schafer (2018, p. 235) stated that there are some procedures in the Directed listening thinking activity (DLTA) as follows:

\section{Choose a story}

2. Teacher reads the title, and displays the first illustration.

3. Teacher asks what the story might be about.

4. Students are allowed to think, and make suggestions.

5. Teacher reads to a pre-determined point, and stops where the plot or action will create excitement.

6. Teacher asks the student to think, and predict what might happen.

7. Teacher tells the students to listen, and find out while the reading continues.

8. At the end story, teacher asks questions to find out how did they know what would happen, and what would they have done.

9. The students might be asked if that was like any previous experience.

\subsection{Hypotheses}

Based on Sugiyono (2015, p. 76) argue that hypotheses is a temporary answer to the formulation of research problems, in which the formulation of research problems has been stated in the form of a question sentence. In relation to the objective of the research above, the writer formulated the following hypotheses:

Ho : It was not effective to teach listening comprehension by using Directed Listening Thinking Activity (DLTA) strategy to the seventh grade students of SMPN 46 Palembang. $\mathrm{Ha} \quad$ : It was effective to teach listening comprehension by using Directed Listening Thinking Activity (DLTA) strategy to the seventh grade students of SMPN 46 Palembang.

\subsection{Research Method}

In this study, the writer used one of experimental method that was pre - experimental design because the result of research obtained more accurate. According to Nunan (2000, p. 221) stated that the experimental researchers are particularly concerned with the issue of external 


\section{JURNAL ILMIAH}

BINA EDUKASI

ISSN 1979-8598 E-ISSN: 2655-8378

http://journal.binadarma.ac.id/index.php/jurnalbinaedukasi

Vol. 14, No. 1, Juni 2021, 59 - 68

validity and formal is specifically designed to enable the researcher to extrapolate the outcomes of the research from the sample to broader population. Meanwhile, Sugiyono $(2015$, p. 25) said that pre-experimental was conducted in one group pre-test and post test design. It means that was compared the pre-test and post test before and after in doing treatment.

\section{$\mathrm{O}_{1} \mathrm{X} \mathrm{O}_{2}$}

Source by Sugiyono $(2015$, p.79) Non Equivalent control group design

Where:
$\mathrm{O}_{1}$ : Pre-test of experimental group
$\mathrm{X}$ : Treatment by using DLTA
$\mathrm{O}_{2}$ : Post-test experimental group

\subsection{Technique for Collecting Data}

In collecting data of this study, the writer used test. According to Arikunto (2010, p. 193)

"Test is a series of questions or exercises used to measure the students' skill, knowledge, intelligence, attitude of an individual or group". In this study, the test was in the form of multiple choice questions and the writer delivered 20 questions both in pre-test and post-test. The test measured the students listening comprehension achievement before and after getting the treatments and to know how far the students can understand what they have learned. The data of this research was collected by giving pre-test and post-test.

\subsection{Technique for Analysis Data}

In analyzing the data, pre-test and post test scores was analyzed. It was analyzed by the writer using one technique of analyzing the data namely paired $t$ - test. It is used to compare the result of pre-test and post test of the experimental group.

\section{FINDINGS AND INTERPRETATION}

\subsection{Findings}

The finding of the research that there were four main findings of this study: (I) the students' score in the pre-test, (2) the students' score in the post-test, (3) level of competency of students' score, (4) pre-test and post-test score comparison.

The writer found out the mean score students' of pre-test, the lowest score pre-test and post-test, and the highest score in pre-test and post-test. The differences between score pre-test and post-test can be seen in analysis paired sample t-test. 


\section{JURNAL ILMIAH}

BINA EDUKASI

ISSN 1979-8598 E-ISSN: 2655-8378

http://journal.binadarma.ac.id/index.php/jurnalbinaedukasi

Vol. 14, No. 1, Juni 2021, 59 - 68

\subsubsection{The Result of the Students' Score of Pre-test}

The students' who participated in the pre-test consisted of 34 students. The pre-test was given to the students before the students were taught teaching listening comprehension by using DLTA strategy. The result of pre-test in the experimental group is displayed in table 1:

Table 1.

The Descriptive Statistic of Pre-test in Experimental Group

\begin{tabular}{|c|c|c|}
\hline $\mathbf{N}$ & $\begin{array}{l}\text { Valid } \\
\text { Missing }\end{array}$ & $\begin{array}{r}34 \\
0\end{array}$ \\
\hline Mean & & 58.38 \\
\hline Std. Error of mean & & 1.396 \\
\hline Median & & 60.00 \\
\hline Mode & & 60 \\
\hline Std. Deviation & & 8.139 \\
\hline Variance & & 66.243 \\
\hline Range & & 35 \\
\hline Minimum & & 40 \\
\hline Maximum & & 75 \\
\hline Sum & & 1985 \\
\hline
\end{tabular}

Based on the table, the result of pre-test in experimental group showed that $\mathrm{N}$ Valid was 34 of students, missing was 0 , mean was 58.38 , standard error of mean was 1.396 , median was 60 , mode was 60 , standard deviation 8.139 , variance was 66.243 , range was 35 , minimum score was 40, maximum score was 75, and total score was 1985 .

\subsubsection{The Result of the Students Score of Post-Test}

The students' who participated in the post-test consisted of 34 students. The post-test was given to the students after treatment. The result of post-test in the experimental group is displayed in table 2:

Table 2.

The Descriptive Statistic of Post-test in Experimental Group

\begin{tabular}{lrr}
\hline $\mathbf{N}$ & Valid & $\mathbf{3 4}$ \\
& Missing & $\mathbf{0}$ \\
Mean & & 72.06 \\
Std. Error of mean & & 1.553 \\
Median & 70.00 \\
Mode & 65 \\
Std. Deviation & 9.055 \\
Variance & 81.996 \\
Range & 35 \\
Minimum & 55 \\
Maximum & 90 \\
Sum & 2450 \\
\hline
\end{tabular}




\section{JURNAL ILMIAH}

BINA EDUKASI

ISSN 1979-8598 E-ISSN: 2655-8378

http://journal.binadarma.ac.id/index.php/jurnalbinaedukasi

Vol. 14, No. 1, Juni 2021, 59 - 68

Based on the table, the result of post-test in experimental group showed that $\mathrm{N}$ Valid was 34 of students, missing was 0 , mean was 72.06, standard error of mean was 1.553, median was 70.00, mode was 65 , standard deviation 9.055, variance was 81.996 , range was 35, minimum score was 55, maximum score was 90, and total score was 2450.

\subsubsection{Pre-Test and Post-Test Score Comparison}

The comparison of score pre-test and post-test in pre-experimental, this research used in paired sample t-test SPSS 17 program, the result of the paired sample statistics could be showed in table 3.

Table 3. Paired Sample T-test

\begin{tabular}{cccccc}
\hline & Mean & N & Std. Deviation & $\begin{array}{c}\text { Std. Error } \\
\text { Mean }\end{array}$ \\
\hline Pair 1 & Post-test & 72.06 & 34 & 9.005 & 1.553 \\
\hline Pre-test & 58.38 & 34 & 8.139 & 1.396 \\
\hline
\end{tabular}

Based on the table above, the mean or average of pre-test was 58.38 Standard deviation of pre-test was 8.139 Standard error mean was 1.396. The mean or average of post-test was 72.06 Standard deviation of post-test was 9.055 standard errors mean was 1.553. The analysis of paired sample t-test can be show on the table 4:

Table 4. Analysis of Paired Sample t-test

\begin{tabular}{|c|c|c|c|c|c|c|c|c|}
\hline & \multicolumn{5}{|c|}{ Paired Differences } & \multirow[b]{3}{*}{$\mathrm{t}$} & & \multirow{3}{*}{$\begin{array}{l}\text { Sig. } \\
(2- \\
\text { tailed })\end{array}$} \\
\hline & \multirow[b]{2}{*}{ Mean } & \multirow{2}{*}{$\begin{array}{c}\text { Std. } \\
\text { Deviation }\end{array}$} & \multirow{2}{*}{$\begin{array}{l}\text { Std. } \\
\text { Errors } \\
\text { Mean }\end{array}$} & \multicolumn{2}{|c|}{$\begin{array}{c}95 \% \text { Confidence } \\
\text { interval of } \\
\text { differences }\end{array}$} & & & \\
\hline & & & & Lower & Upper & & $\mathrm{df}$ & \\
\hline $\begin{array}{l}\text { Pair Post-test } \\
1\end{array}$ & 13.676 & 3.548 & .608 & 12.438 & 14.914 & 22.476 & 33 & .000 \\
\hline
\end{tabular}

Based on the analysis in table 3.4, it was found that the average score of students in the post-test was 13.676 , the standard deviation was 3.548 , the standard error mean was 0.608 , while in the level $95 \%$ confidence interval of the difference it was found that the lower score was 12.438 , the upper score was 14.914. Then, the degree of freedom (df) was 33 and the value of t-obtained was 22.476 higher than the value of t-table was 2.0345 and the last significance (2- tailed) was 0.000 (see table 3.4). Since 0.000 (sig 2-tailed) was lower than alpha value 0.05 , it was inferred that the Directed Listening Thinking Activity (DLTA) strategy taught in the experimental group was effective to teach listening comprehension. 


\section{JURNAL ILMIAH \\ BINA EDUKASI \\ ISSN 1979-8598 E-ISSN: 2655-8378 \\ http://journal.binadarma.ac.id/index.php/jurnalbinaedukasi \\ Vol. 14, No. 1, Juni 2021, 59 - 68}

\subsection{Interpretation}

Based on the results of data analysis, the findings showed that there was a progress from the scores of pre-test and post-test in pre-experimental group. The average of pre-test in preexperimental was 58.38, Standard deviation of pre-test was 8.139, Standard error mean was 1.396 and the average of post-test was 72.06, Standard deviation of post-test was 9.055, Standard error mean was 1.553 .

From the result of paired sample test showed that comparison between pre-test and posttest in pre-experimental (value t-obtained) was 22.476 higher than $\mathrm{t}$-table was 2.0345 . And the significance (2-tailed) was 0.000 lower than 0.05 . Then, the degree of freedom (elf) was 33. Since t-obtained was higher than $\mathrm{t}$ - table, so that the null hypothesis $\left(\mathrm{H}_{\mathrm{o}}\right)$ was rejected and alternative hypothesis $\left(\mathrm{H}_{\mathrm{a}}\right.$, ) was accepted. It could be stated that the teaching listening comprehension by using DLTA strategy was effective.

\section{CONLUSION}

Based on the result of data gained during the experiment, the writer could draw three conclusions, they were stated : (I) Teaching listening comprehension by using Directed Listening Thinking Activity (DLTA) strategy to the seventh grade students of SMPN 46 Palembang was one of the effective model to increased the students' in listening comprehension. (2) Before applying by using Directed Listening Thinking Activity (DLTA) strategy to the seventh grade students of SMPN 46 Palembang, the students' average score their ability was in the fair level. (3) After applying by using Directed Listening Thinking Activity (DLTA) strategy to the seventh grade students of SMPN 46 Palembang, the students' average score increased to good level. It means that the null hypotheses were rejected and consequently the alternative hypotheses were accepted. It could be stated that the teaching listening comprehension by using Directed Listening Thinking Activity (DLTA) strategy was effective.

Based on the conclusions above to improve teaching and learning activities in the class especially in Teachers of English are suggested to used Directed Listening Thinking Activity (DLTA) strategy in teaching listening comprehension, because it is a good strategy and it is proved by the writer's experiment result that the students be more active and they did not get bored in learning process and motivate the students, so they can pay more attention and study hard in learning English. Especially in listening comprehension by using Directed Listening Thinking Activity (DLTA) strategy and for the institutions are expected to facilitate the learning process such as speaker, tape recorder and projector in language laboratory. 


\section{JURNAL ILMIAH}

BINA EDUKASI

ISSN 1979-8598 E-ISSN: 2655-8378

http://journal.binadarma.ac.id/index.php/jurnalbinaedukasi

Vol. 14, No. 1, Juni 2021, 59 - 68

\section{REFERENCES}

Al-Khayyat, A. S. J. (2015). The impact of Directed Listening Thinking Activity (DLTA) on developing university students' listening competencies. Internal Journal of English and Education, 4(4), 1-20.

Arikunto, S. (2010). Prosedur penelitian suatu pendekatan praktik. Jakarta: Rineka Cipta.

Barone, D. M., Mallette, M. H., \& Xu, S. H. (2005). Teaching Early Literacy. New York: The Guilford Press.

Dalton, S. S. (2007). Five standards for effective teaching: How to succeed with all learners. United States: John Wiley \& Sons, Inc.

Downs, J. (2008). Listening Skills Training. New York: ASTD Press.

Nunan, D. (2000). Language Teaching Methodology: A textbook for teachers. Malaysia: Longman.

Nunan, David. (2003). Practical English Language Teaching Speaking. Singapore: The McGraw Hi II Companies, Inc., first.

Oktaviani, R. N. (2013). Implementation of Directed Listening and Thinking Activity (DLTA) strategy to increase listening skill to the grade students of elementary school. Journal of English and Education, 1(2), 1-10.

Schafer, A. . (2018). Learning and Teaching English with the new media. Germany: Creative Commons Attribution.

Sugiyono. (2015). Metode Penelitian dan Pengembangan Pendekatan Kualitatif, Kuantitatif, dan $R \& D$. Bandung: CV. Alfabeta. 